\title{
ERRATUM
}

\section{THE ASSOCIATION BETWEEN ADULT MORTALITY RISK AND FAMILY HISTORY OF LONGEVITY: THE MODERATING EFFECTS OF SOCIOECONOMIC STATUS - Erratum}

\author{
OWEN F. TEMBY AND KEN R. SMITH
}

doi: $10.1017 / \mathrm{S} 0021932013000515$, published online by Cambridge University Press 8 October 2013

Page 724, lines 37 and 38, should read:

Familial excess longevity (FEL). Familial excess longevity is a measure of an individual's history of longevity among his or her blood relatives (Kerber et al., 2001).

\section{Reference}

Owen F. Temby and Ken R. Smith (2014) The association between adult mortality risk and family history of longevity: the moderating effects of socioeconomic status. Journal of Biosocial Science 46, 721-734. 